\title{
Modeling sediment accumulation in North American playa wetlands in response to climate change, 1940-2100
}

\author{
Lucy Burris • Susan K. Skagen
}

Received: 18 January 2012 / Accepted: 28 July 2012 /Published online: 11 August 2012

C The Author(s) 2012. This article is published with open access at Springerlink.com

\begin{abstract}
Playa wetlands on the west-central Great Plains of North America are vulnerable to sediment infilling from upland agriculture, putting at risk several important ecosystem services as well as essential habitats and food resources of diverse wetland-dependent biota. Climate predictions for this semi-arid area indicate reduced precipitation which may alter rates of erosion, runoff, and sedimentation of playas. We forecasted erosion rates, sediment depths, and resultant playa wetland depths across the west-central Great Plains and examined the relative roles of land use context and projected changes in precipitation in the sedimentation process. We estimated erosion with the Revised Universal Soil Loss Equation (RUSLE) using historic values and downscaled precipitation predictions from three general circulation models and three emissions scenarios. We calibrated RUSLE results using field sediment measurements. RUSLE is appealing for regional scale modeling because it uses climate forecasts with monthly resolution and other widely available values including soil texture, slope and land use. Sediment accumulation rates will continue near historic levels through 2070 and will be sufficient to cause most playas (if not already filled) to fill with sediment within the next 100 years in the absence of mitigation. Land use surrounding the playa, whether grassland or tilled cropland, is more influential in sediment accumulation than climate-driven precipitation change.
\end{abstract}

\section{Introduction}

Shallow depressional wetlands across the North American Great Plains provide important ecosystem services, including ground-water recharge, storm-water retention, carbon storage, and provision of resources and habitats for the maintenance of biodiversity (Gurdak and Roe 2010; Haukos and Smith 1994; Smith et al. 2011). These geographically dispersed and

Electronic supplementary material The online version of this article (doi:10.1007/s10584-012-0557-7) contains supplementary material, which is available to authorized users.

L. Burris $(\bowtie) \cdot S$. K. Skagen

Fort Collins Science Center, U.S. Geological Survey, 2150 Centre Avenue, Bldg. C,

Fort Collins, CO 80526, USA

e-mail: lburris@rams.colostate.edu 
hydrologically isolated wetlands provide critical habitats for plants, invertebrates, and vertebrates, including many taxa of amphibians, mammals, and migrant wetlanddependent birds such as sandhill cranes (Grus canadensis), waterfowl, and shorebirds (Ghioca-Robrecht et al. 2010; Haukos and Smith 1994; Skagen et al. 1999; Webb et al. 2010). Collectively, prairie wetlands are highly vulnerable to land conversion, agricultural policies and practices, hydrology alteration, and water pollution. Today, ground-water withdrawal, increasing rates of sedimentation, and enhanced likelihood of drought due to climate change pose far-reaching conservation challenges for wetland-dependent biota.

Precipitation-filled playa wetlands, or shallow ephemeral wetlands lined with an impermeable subsurface clay layer, dispersed across the west-central Great Plains are especially affected by climate dynamics. Playas may be inundated annually or only once per decade, depending upon recent rainfall, geographic location, surrounding land use and size (e.g., Johnson et al. 2011b), and these hydrologic cycles have important effects on biotic response (e.g., phenology and composition of plant and animal communities). Wet-dry fluctuations, created by the interplay of inundation, percolation, evaporation, and transpiration, provide ephemeral habitats ranging from shallow water to dry ground with associated variation in flora and fauna (Cariveau et al. 2011; Euliss et al. 2004).

Climate predictions from atmospheric-oceanic general circulation models (AOGCMs) suggest higher summer temperatures across the western Great Plains and reduced summer precipitation in the south (Christensen et al. 2007: Fig. 11.12). Whereas precipitation-based runoff is projected to decrease due to the combination of increased temperature and reduced precipitation (Intergovernmental Panel on Climate Change [IPCC] 2007: Fig. 3.5), recent trends have shown an increase in storm intensity (fewer storms delivering more precipitation [Karl et al. 1995]). The combined effects of temperature increases, precipitation changes, and surrounding landscape may significantly impact runoff-driven sedimentation rates and playa inundation period.

Among many land use impacts, sedimentation is a primary threat to the continued existence of playas at the regional scale (Smith 2003). Although sedimentation is a natural process, sediments accumulate at a faster rate in playas in agricultural settings than in grasslands (Johnson 2011; Luo 1994; Luo et al. 1997; Tsai et al. 2007, 2010) as a result of runoff-borne materials. Of playas that existed in the Southern High Plains (eastern New Mexico, Oklahoma panhandle, and western Texas) before 1970, $60 \%$ may no longer fulfill vital ecological functions (e.g., ground-water recharge, provision of habitat and resources for plant and animal communities) due to anthropogenic sedimentation and modification and $20 \%$ may be completely gone (Johnson 2011). Native biota, and especially migratory birds, positively respond to the presence of individual playas, to their timing and length of inundation (hydroperiod), their area, and the area and density of playas in the surrounding landscape (Cariveau and Pavlacky 2009; Smith 2003).

Sediment delivery represents a critical nexus between land-use patterns and weather (climate) because heavy precipitation on exposed soil causes erosion, overland transport and deposition of sediments. Therefore, the need for understanding sedimentation patterns and processes to develop soil conservation practices that consume little water (allowing it to pass to wetlands) is critical as climate change increases vulnerability of shallow depressional wetlands.

To address this need, we examined the relative roles of projected changes in precipitation and land use context in the playa sedimentation process across the west-central Great Plains. We modeled rates of sedimentation, sediment depths, and resultant playa wetland depths from 1940 through 2100. We estimated erosion using the Revised Universal Soil Loss Equation (RUSLE; Renard et al. 1997), an analysis approach at the regional scale which 
retained evaluation of individual playa wetlands and their surrounding landscapes, and included upland land use, topography, erosivity (estimated from precipitation), soil texture, and conservation practices. RUSLE was an appealing approach for both landscape scale analysis and future scenario evaluation due to its small number input parameters and is currently used when erosion analyses are conducted with limited historical information or beyond field-scales. We used regional monthly climate predictions (Coulson et al. 2010) that included influences such as latitude, longitude, and elevation. The resulting spatially explicit predictions of playa longevity based on land use patterns and climate will inform conservation planning for these critical wetlands and the diverse biota dependent upon them.

\section{Methods}

\subsection{Study area}

The playa region of the west-central Great Plains (Fig. 1) extends from Nebraska through the panhandle of Texas, including parts of Colorado, New Mexico, Kansas, and Oklahoma (ca $780,000 \mathrm{~km}^{2}, 30.8-43.6^{\circ} \mathrm{N}$ latitude, $96.4-105.3^{\circ} \mathrm{W}$ longitude). Because the area is generally encompassed by the Great Plains Landscape Conversation Cooperative (GPLCC), we used their boundary for our study extent (http://www.fws.gov/gis/data/national/index.html). The vast Ogallala Aquifer underlies much of this area. Vegetation is dominated by warm and cool season short grass prairie and agricultural crops (Smith 2003).

Playa wetlands are distinguished by lack of outlet drainage, circular to ellipsoidal shapes, hydric soils and vegetation, and impermeable subsurface clay horizons (Smith 2003). In general, they range in size from less than 1 ha to several hundred hectares (Smith 2003). We limited our analyses to playas and excluded reservoirs, lakes, rivers, stock ponds, and rainwater basins. Due to modifications by plowing, road bisection, and dredging, our estimate of roughly 80,000 (see below) water bodies on the west-central Great Plains may underestimate the number of playa wetlands present before 1860 and overestimate the

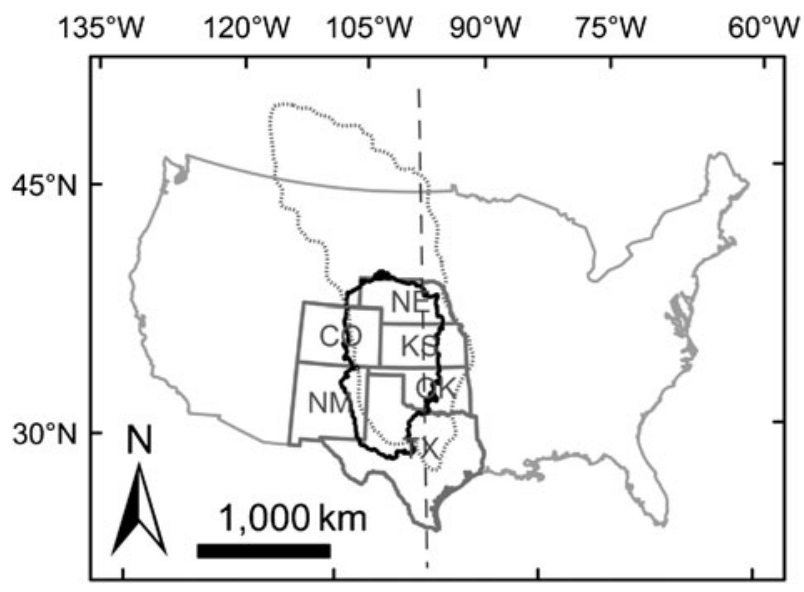

Fig. 1 Boundary of the west-central Great Plains study area, coincident with the Great Plains Landscape Conservation Cooperative (solid line), and full extent of Great Plains (hatched line). Study area was truncated to the east of $98.4^{\circ} \mathrm{W}$ (dashed vertical line), removing $1 \%$ of all playas. State names: CO, Colorado; KS, Kansas; NE, Nebraska; NM, New Mexico; OK, Oklahoma; SD, South Dakota; TX, Texas; WY, Wyoming 
number of functional playas remaining (Johnson 2011). Our study period began in 1940 when irrigated agriculture intensified (Allen et al. 2005; Brown et al. 2005; Luo 1994; Rosenberg et al. 1999).

\subsection{Model and data preparation}

We used the RUSLE (Renard et al. 1997) to model sediment loss from uplands surrounding playas:

$$
T_{u p}=R K L S C P
$$

where $\mathrm{T}_{\text {up }}$ was annual soil mass loss per unit area, $\mathrm{t} \mathrm{ha}^{-1} \mathrm{yr}^{-1}$ with $\mathrm{t}$ in metric tons. $\mathrm{R}$ was soil rainfall erosivity, $\mathrm{MJ} \mathrm{mm} \mathrm{ha}{ }^{-1} \mathrm{hr}^{-1} \mathrm{yr}^{-1}$. The time interval of $\mathrm{R}$ determined the time interval for the units of $\mathrm{T}_{\mathrm{up}}$. $\mathrm{K}$ was the soil erodibility factor, $\mathrm{t}$ ha $\mathrm{hr} \mathrm{ha} \mathrm{CJ}^{-1} \mathrm{Mm}^{-1}$. LS was the dimensionless topographic factor. $\mathrm{T}_{\text {up }}$ then represented the mass of sediment lost from a single upland unit area per unit time. $\mathrm{C}$ was the cover management factor, dimensionless, determined from land cover. $\mathrm{P}$ was the conservation practice factor, dimensionless, and customarily set to one for large areas unless comparing specific field practices.

The volume of sediment displaced from the upland was equal to the sediment deposited in the playa, $V_{\text {playa }}=\mathrm{V}_{\text {upland, }}$, where $V_{\text {upland }}=\mathrm{T}_{\text {up }} / \rho_{\text {up }}$ summed over the upland area, where $\rho_{\text {up }}$ ( $\mathrm{g} \mathrm{cm}^{-3}$, bulk density). Sediment depth was the volume of sediment divided by the area of the playa, $\mathrm{SDepth}=\mathrm{V}_{\text {playa }} / \mathrm{A}_{\text {playa. }}$ In these calculations, we made the following simplifying assumptions: (1) all eroded sediment arrived at the playa, and (2) playas were flat-bottomed and evenly filled. We recognized that sediment texture, slope steepness, aeolian redistribution, presence of prior sediments, and runoff intensity all contribute to the actual location of sediment deposition within the playa. However, we lacked sufficient information for each playa to make more than a simplified assumption of uniform filling. To account for redeposition of sediments along the slope and inherent RUSLE assumptions, and to avoid using an arbitrary sediment delivery ratio, we calibrated our estimated sediment depths to field measurements reported by Luo (1994) (see below).

We used a geographical information system (GIS, ESRI ArcGIS 9.3 1999-2008) to create spatial data sets and performed raster calculations to evaluate SDepth at each playa in the study area (process model available in Online Resource, Fig. 1). Data sets included playas, land use, elevation, soil properties, roads, and precipitation clipped and projected to a common footprint and datum (details available in Online Resource, Details of RUSLE Computations). We developed a playa dataset of ca 78,000 potential playas; discarding any playa that had low circularity, non-eroding uplands, or undefined soil erodibility.

Gridded monthly total precipitation estimates were obtained from Coulson et al. (2010) for historic years, 1940-2000, based on PRISM (Parameter-elevation Regressions on Independent Slopes Model, http://www.prism.oregonstate.edu/) normals from 1961-1990. Coulson et al. (2010) also provided monthly future precipitation for 2010-2100 using the PRISM normals and three AOGCMs: Australian Commonwealth Scientific and Industrial Research Organization CSIRO-MK3.5, Canadian Centre for Climate Modeling and Analysis model CGCM2.1MR, and Japanese Centre for Climate System Research Model for Interdisciplinary Research on Climate MIROC Version 3.2; and three IPCC 4th Assessment Report (IPCC 2007) emission scenarios: A1B, A2, and B1 (broadly, representing continuing current greenhouse gas emission rates, significant emissions increases, and emissions reduction, respectively). All precipitation values were upscaled from a 2.5 arc minute (PRISM data) or downscaled (AOGCM models) to a 5 arc minute grid. Coulson et al. (2010) downscaled the three AOGCM 
data sets using first a change factor approach (the difference in monthly temperature at each AOGCM location from the 30-year PRISM 1961-1990 mean or the ratio of monthly precipitation to 30-year PRISM mean) and then using ANUSPLIN software (a thin-plate spline approach using multivariate linear regression with a smooth nonparametric function where the resulting climate variable is dependent upon latitude, longitude, and elevation [Hutchinson 1995; McKenney et al. 2005; Price et al. 2004]) to interpolate the change factor values for the prediction period. We summed monthly precipitation values to obtain annual precipitation at each grid point. For visualization purposes we averaged annual precipitation for two historic and three future periods: 1941-1970, 1971-2000, 2011-2040, 2041-2070, and 2071-2100. We selected a 30-year reference interval of 1971-2000 to include the IPCC baseline period of 1980-1999 (Christensen et al. 2007). To assess the range of variability of the predictions, we examined the annual precipitation at each grid point and selected the "driest" and "wettest" model/scenario during each future period. The driest (wettest) model/scenario had the most grid points with the lowest (highest) precipitation.

Using average annual precipitation (P) and our driest and wettest model/scenarios, we calculated annual R-factor values after Renard and Freimund (1994:Eqs. 11, 12).

$$
\begin{gathered}
R=0.04830 P^{1.61} \text {, when } P<=850 \mathrm{~mm} / y r \text { or } \\
R=587.8-1.219 P+0.00415 P^{2}, \text { when } P>850 \mathrm{~mm} / \mathrm{yr}
\end{gathered}
$$

The R-factor at each grid point for each year was summed for four periods: 1941-1992, 2011-2040, 2041-2070, and 2071-2100. The historic period 1941-1992 allowed comparison to field results reported in Luo (1994). Future periods were selected to provide consistent 30-year intervals. Using ArcGIS, these point values were used to generate an $\mathrm{R}$-factor surface using inverse distance weighting with a power of 2 and 12 nearest points. We extracted the R-factor value at the centroid of each watershed and assumed it to be valid across the watershed (average watershed size $\sim 1 \mathrm{~km}^{2}$ ).

Meso-scale ( 30-m) upland land use was extracted from the National Land Cover 2001 dataset (http://datagateway.nrcs.usda.gov). Conservation Reserve Program (CRP) land use was not explicitly indicated in this dataset, but we confirmed grassland presence for a small sample of known CRP locations. We were unable to distinguish between native and introduced grasslands or to identify buffer strips below the $30-\mathrm{m}$ resolution of the dataset. We assumed land use (grassland vs. cropland) was unchanged from 1940 through 2000 (44.5\% and $44.9 \%$ agricultural lands in non-metropolitan areas in 1949 and 2000, respectively; Brown et al. 2005: Appendix; Parton et al. 2005) continuing to 2100. We obtained large-scale (sub-county) C-factor values from the 1997 National Resources Inventory (Natural Resources Conservation Service 2000). Land cover and C-factors were compared by state (Online Resource Table 1 ) to link C-factor values to generalized land use categories of grassland (C-factor $=0.01)$, pasture (0.02), cropland (0.22), and other (0). Within the cropland category, $\mathrm{C}$-factor values ranged from hay $(0.02)$ to wheat $(0.12-0.21)$ to irrigated corn $(0.35)$ and cotton $(0.35-0.7)$. Use of a generalized crop C-factor potentially underestimated or overestimated erosion in particular locations but avoided the need to consider within and between year crop shifts.

We averaged sediment estimates across the nine climate model/emission scenarios to obtain a single estimate of sediment depth for each playa. We calibrated our estimated sediment depths to field measurements reported by Luo (1994) who collected sediment samples from 40 random playas situated in grassland (20 playas) or cropland with watershed 
areas of at least 64 ha, playa areas of 4-10 ha, upland slopes of less than $3 \%$, playa depths of less than $2 \mathrm{~m}$, circular or ellipsoidal shapes, "fine" or "medium" texture, and located in eleven Texas counties.. Since we did not know specifically which playas were measured, we extracted all playas in our dataset which matched these criteria. We defined "grass" and "crop" uplands as those composed of least $95 \%$ grassland or cropland, respectively. We compared our mean sediment depths to the mean depths reported by Luo (1994) by land use. Using a mixture model, we developed a linear relationship setting Luo's reported average sediment depth equal to our RUSLE predicted sediment depth (SDepth) multiplied by a local sediment delivery index based on the relative contributions of watershed grass and crop use.

$$
\begin{aligned}
& \text { LuoAvgSedimentDepth } \approx \text { CalSDepth } \\
& \quad=\operatorname{SDepth}\left(a_{1} \frac{\% \text { grass }}{\% \text { grass }+\% \text { crop }}+a_{2}\left(1-\frac{\% \text { grass }}{\% \text { grass }+\% \text { crop }}\right)\right)
\end{aligned}
$$

where $\mathrm{a}_{1}$ and $\mathrm{a}_{2}$ were determined by the model fit of our data to Luo's data. We calibrated our results using this relationship.

We used the average annual deposition rate from 1941-1992 to estimate sedimentation through 2010. Using projected R-factors, we estimated future accumulation for the periods 2011-2040, 2041-2070, and 2071-2100 averaged across the nine climate model/scenario combinations. Within each period, we averaged the annual accumulation rates to obtain a single average rate for the 30-year period. Playa fill times were determined by the number of years needed to fill the remaining playa depth (minimum playa perimeter elevation minimum playa interior elevation). We assumed surface elevations corresponded to the vintage of the underlying DEM (which ranged from 1920-1959, which we averaged to 1940, 1960-1979 averaged to 1970, and 1980-1999 averaged to 1990 [USGS National Elevation Dataset Data Source Index, http://ned.usgs.gov/usgs_gn_ned_dsi/viewer.htm]). Most DEM values were from 1970 DEMs, so generally our estimated playa depth loss due to sediment accumulation started in 1970 . We counted playas filled by 1992 , during 1993-2010, during 2011-2040, during 2041-2070, and during 2071-2100, and those that remained unfilled.

\subsection{Analysis}

To examine area-wide precipitation patterns, we extracted average annual precipitation at 70 random locations across the study area for each of our comparison periods 1941-1970, 2011-2040, 2041-2070, 2071-2100 and calculated the difference of the average annual precipitation at those points from the reference period of 1971-2000. To minimize possible spatial correlation at small scales, our points were separated by a minimum of $70 \mathrm{~km}$ (Augustine 2010). We used an analysis of variance (ANOVA, SAS Institute SAS 9.3 2002-2010) to test for the average difference in precipitation for the four periods and constructed $95 \%$ confidence intervals on the mean difference by period to test for nonzero mean differences.

We compared calibrated RUSLE predictions area-wide to field data by Luo (1994). Because comparable field measurements have not been found for other areas, we used quantile regression (Koenker 2010; R Development Core team 2010) to compare our RUSLE predicted sediment accumulation at playas matching criteria from Luo (1994) for the period from 1941-1992. Because of the small numbers of matching playas found in Kansas, Nebraska, New Mexico, and Oklahoma, we assigned playas to three groups: playas in Luo's study area, southern playas (all other Texas playas, New Mexico, and Oklahoma), 
and northern playas (Colorado, Kansas, Nebraska). We computed $95 \%$ confidence intervals for the mean accumulated sediment depth by surrounding land use (crop or grass) at 0.1 , $0.25,0.5,0.75$, and 0.9 quantile intervals (which contain cumulatively $10 \%, 25 \%$, etc., of the response variable values). We used ANOVA (R Development Core Team 2010) on land use and period factors for mean sediment accumulation at playas which matched Luo's criteria that were unfilled by 2070 for two 50-year periods: 1940-1992 (historic precipitation) and 2010-2062 (average, driest scenarios, and wettest scenarios).

\section{Results}

Nearly $90 \%$ of playas of the west-central Great Plains were vulnerable to sediment infill by 2100 (Fig. 2, Table 1). Based on average future precipitation, land use had a stronger influence on sedimentation rates than precipitation; sediment accumulation decreased by ca $4 \mathrm{~cm}$ across 50 years $(t=22.8, d f=3968, P<0.0001$; Table 2$)$ compared to an increase in sedimentation due to land use change from grassland to cropland of ca $24 \mathrm{~cm}$ across 50 years $(t=-3.82, d f=3968, P<0.0001)$. Sediment accumulation in cropland settings also was significantly higher than in grasslands under both the driest and wettest scenarios (Table 2). Under the driest scenarios with reduced sediment accumulation, 563 of 3968 (14\%) playas filled one 30 -yr period later than predicted under average predicted precipitation; under the wettest scenarios $384(10 \%)$ playas filled one period sooner.

During the reference period 1971-2000, precipitation within the study region ranged from ca 285 to $720 \mathrm{~mm} / \mathrm{yr}$, increasing from west to east (Fig. 3, left). The 30-year average annual precipitation during this reference period was greater than precipitation during the historic period of 1941-1970 and greater than projected average precipitation in future periods (2011-2040, 2041-2070, 2071-2100) (Fig. 3, right; ANOVA $F_{3,276}=5.64, P=0.0009$; mean difference $(95 \%$ confidence interval of the difference $)=-35.1(-41.9,-28.2),-31.4(-38.6$, $-24.1),-13.0(-23.1,-2.9),-25.5(-33.4,-17.7)$, respectively). Our driest and wettest model/ scenario combinations varied by period: during 2010-2040 and 2041-2070 MIROC A1B was the driest at 5762 of 9172 grid points and 5403 points, respectively; during 2071-2100 MIROC A2 was the driest at all 9172 points. The wettest combinations during these periods were CSIRO A2 (at 4136 points), CSIRO B1 (9172) and CSIRO A1B (8826), respectively. The coefficient of variation of the precipitation at each grid point across all nine model/scenario combinations and periods $(n=27517)$ averaged $12.8 \%$, ranging from $4.6 \%$ to $22.5 \%$. The coefficient of variation for the R-factors based on these precipitation values averaged $21.5 \%$ $(7.7 \%-37.8 \%)$.

The final proposed playa layer for our entire study area contained ca 78,000 playas. Playa attributes varied from north to south and east to west across the region, with more numerous playas in Nebraska, Texas, and Kansas; larger playas and watersheds in the south; and more grassland matrix in the west (Table 1, Fig. 4). In comparison with Ekanayake et al. (2009), our average watershed area of 107.6 ha compared favorably with their estimates of 110.32 for survey (considered to be "truth") and 118.76 for minimum distance methods. The vast majority (93\%) of our playas were less than $0.3 \mathrm{~m}$ deep. Due to shallow depth and upland cultivation, playas in the northern portion of our study area were at risk of earlier sediment infill (loss of depth between perimeter low point and playa bottom) than those in the south.

We calculated calibration factors to relate erosion to sedimentation rates based on work by Luo (1994) who identified 11,939 playas in his study area; in the same area we found 12,232 playas. Of these, 1975 fit Luo's criteria exclusive of land use, and 230 of these also matched his more stringent land use criteria (176 exclusively in $\geq 95 \%$ cropland and 54 in 


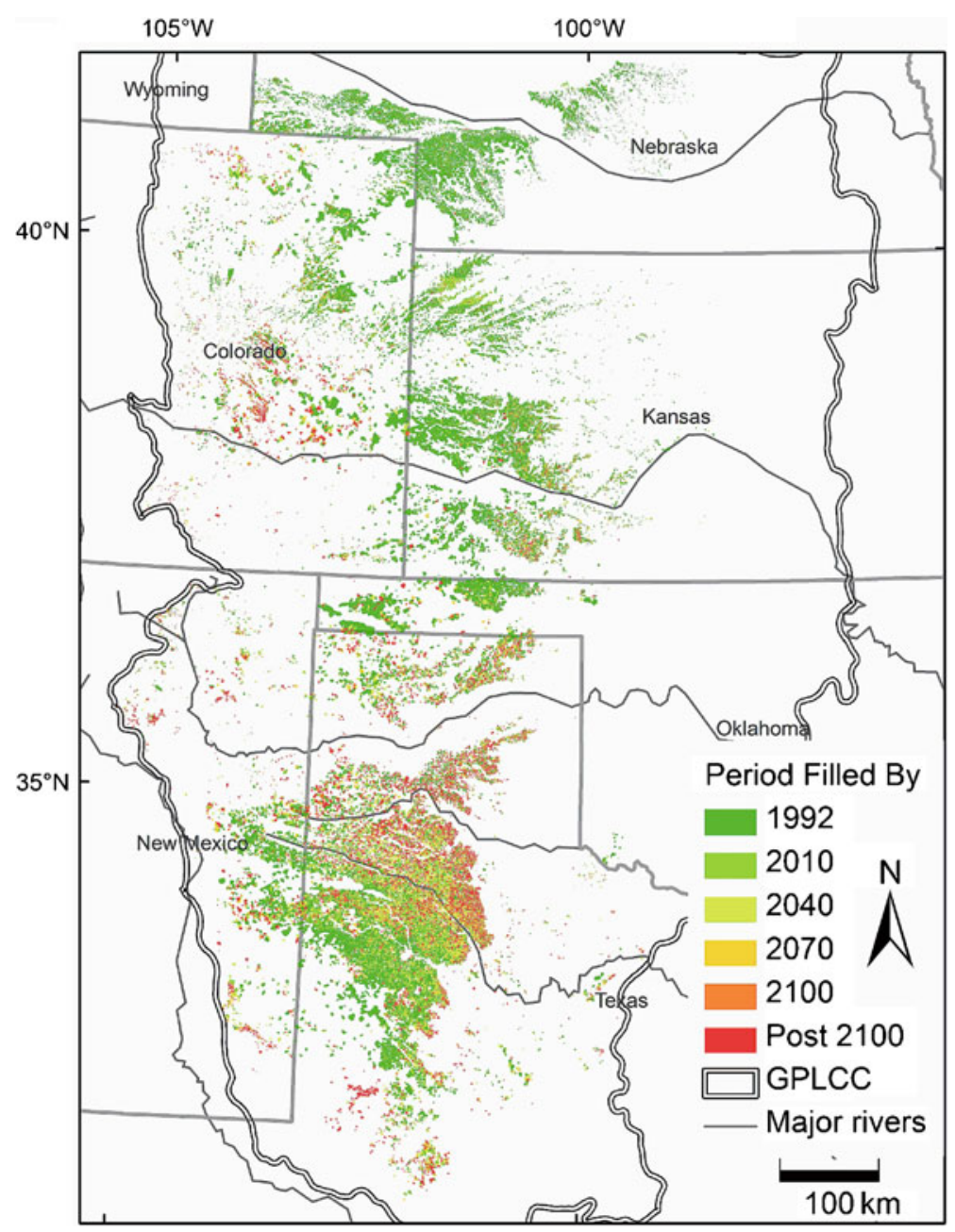

Fig. 2 Period (ending 1992, 2010, 2040, 2070, or 2100) by which each playa within the study area will be filled with sediment based on calibrated RUSLE (Revised Universal Soil Loss Equation) estimation and historic and downscaled annual precipitation predictions though 2100. To improve visibility, playa watersheds are shown; each watershed contains a single playa

$\geq 95 \%$ grassland). In this 11-county area, our estimated mean sediment depth at all playas matching Luo's criteria was $3.14 \mathrm{~cm} / 50$ years $(2.56,3.72 ; 54$ playas) in grasslands and $64.55 \mathrm{~cm} / 50$ years $(59.19,69.91 ; 176$ playas $)$ in croplands compared to Luo's sample means of $4.62(2.83,6.42 ; 20$ playas in grassland) and $42.12(31.4,52.8 ; 20$ playas in cropland), respectively. Our resulting calibration factors were $a_{1}=1.473$ and $a_{2}=0.653$ (Eq. 4, above). Our average calibrated sediment depths were $4.61(3.76,5.46)$ in grassland and 42.36 $(38.85,45.87)$ in cropland. Proportionally fewer playas matched Luo's criteria in the remainder of our study area due to mixed land use, playa size, and soil texture differences. The southern region (the remaining Texas counties, New Mexico, and Oklahoma) contained ca 14,000 playas of which 115 met Luo's criteria, and the northern part of our study area (Colorado, Nebraska, and Kansas) contained ca 52,000 playas of which 206 met Luo's criteria. 


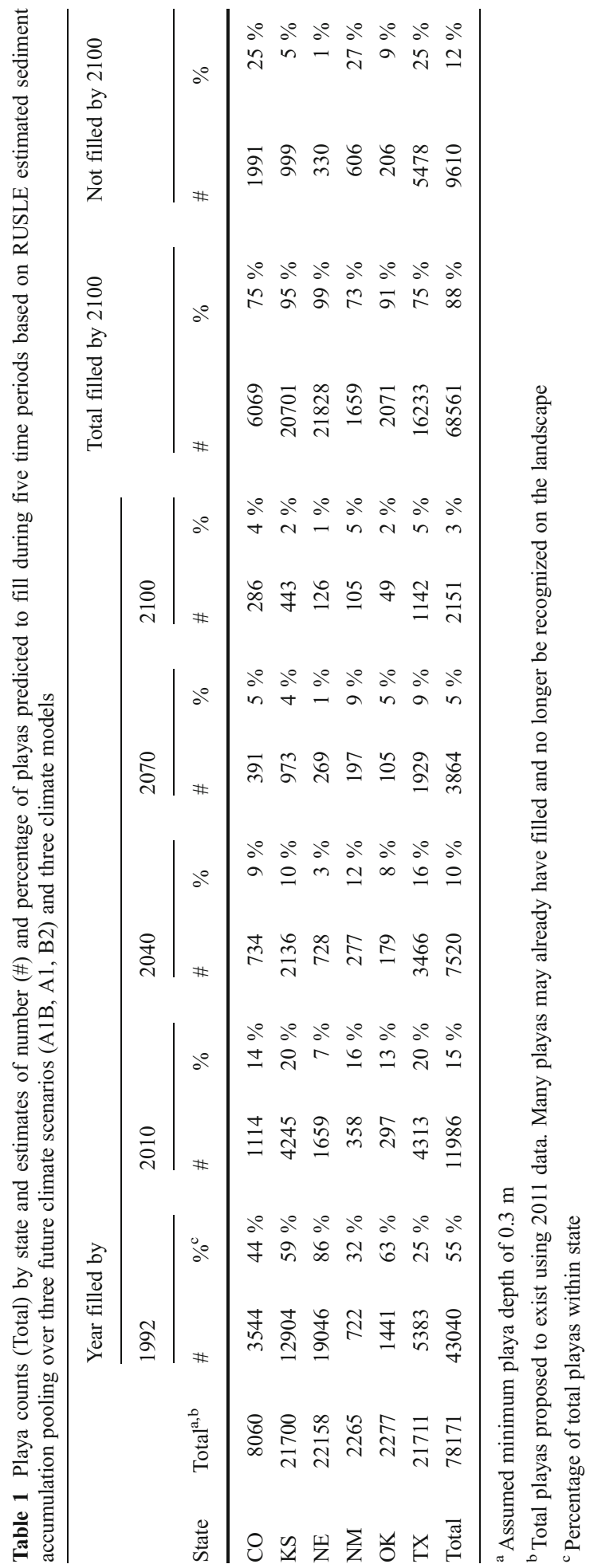


Table 2 Least squares means of sediment accumulation depth $(95 \% \mathrm{CI}, \mathrm{cm})$ by land use and climate for a subset of playas (those predicted to fill after 2070, $n=3,968)$ during historic (1940-1992) and future (20102062) time periods with historic and predicted precipitation conditions (average, driest, and wettest). Playas were situated in either grassland or cropland settings

\begin{tabular}{|c|c|c|c|}
\hline \multirow[t]{2}{*}{ Time period } & \multicolumn{2}{|l|}{ Surrounding upland } & \multirow{2}{*}{$\begin{array}{l}\text { Difference between } \\
\text { land uses }\end{array}$} \\
\hline & $\begin{array}{l}\text { Grassland } \\
(n=1,148 \text { playas })\end{array}$ & $\begin{array}{l}\text { Cropland } \\
(n=2,820 \text { playas })\end{array}$ & \\
\hline 1940-1992 & $27.1(24.6,29.6)$ & $51.8(50.2,53.4)$ & $24.7(21.7,27.6)^{* * *}$ \\
\hline Average precipitation, 2010-2062 & $24.6(22.1,27.1)$ & $47.7(46.1,49.3)$ & $23.1(20.2,26.1)^{* * *}$ \\
\hline Difference from 1940-1992 & $-2.5(-6.1,1.0)^{\mathrm{ns}}$ & $-4.1(-6.3,-1.8)^{* *}$ & \\
\hline Dry scenarios, 2010-2062 & $18.9(16.4,21.4)$ & $35.6(34.0,37.2)$ & $16.7(13.7,19.6)^{* * *}$ \\
\hline Difference from 1940-1992 & $-8.2(-11.7,-4.7)^{* * *}$ & $-16.2(-18.4,-13.9)$ & \\
\hline Wet scenarios, 2010-2062 & $32.9(30.4,35.4)$ & $63.3(61.7,64.9)$ & $30.4(24.5,33.4)^{* * *}$ \\
\hline Difference from 1940-1992 & $5.77(2.2,9.3)^{* *}$ & $11.5(9.3,13.8)^{* * *}$ & \\
\hline
\end{tabular}

** $P<0.001, * * * P<0.0001$, ns $P>0.05$

All $|\mathrm{t}|>3.2, d f \geq 2296$

In general, we obtained good agreement between calibrated sediment depth at these playas and Luo's sample of playas based on overlapping $95 \%$ confidence intervals at all quantile values (Fig. 5) in both grassland and cropland settings, indicating RUSLE results were congruent regardless of geographic location. In essence, at geographic locations outside of the calibration counties, we found a similar distribution of sediment depths as Luo as assessed by quantiles (e.g., in cropland settings $25 \%$ of the playas had $<40 \mathrm{~cm}$ of sediment regardless of location, $50 \%<60 \mathrm{~cm}$, and so forth).

\section{Discussion}

Land use surrounding playas is more influential than climate-driven precipitation change in determining rates of sediment accumulation within the playas. Within a 30-year time period, playas embedded in cropland matrices may accumulate nearly twice the depth of sediments as playas surrounded by grassland. In contrast, our results suggest that contemporary and future predicted rates of sediment accumulation within a given land use context do not differ. Smith et al. (2011: Fig. 3) also observed a stronger influence of land use than climate on playa hydroperiod based on temperature simulations and proposed sediment removal as a practice that potentially can restore playa hydrology.

Accelerated sediment accumulation in cropland playas is detrimental to native biota. As little as $0.5 \mathrm{~cm}$ of sediment is sufficient to suppress seedling and invertebrate emergence in the prairie pothole wetlands of North America (Gleason et al. 2003), and if this pattern holds in playa systems, rapid accretion of sediment will depress aquatic invertebrates, the key protein for resident and migrating wetland-dependent birds. Wetland-dependent plant richness is reduced by loss of wetland volume and presence of upland agriculture (Tsai et al. 2012). Further, sediments can also mask underlying hydric soils, compromising wetland delineation efforts and thus environmental protection, leaving more playas vulnerable to development (Johnson et al. 2011a).

The spatial patterns of predicted playa longevity presented here may help identify landscapes for playa conservation or more intensive research.. Many playas within the west- 


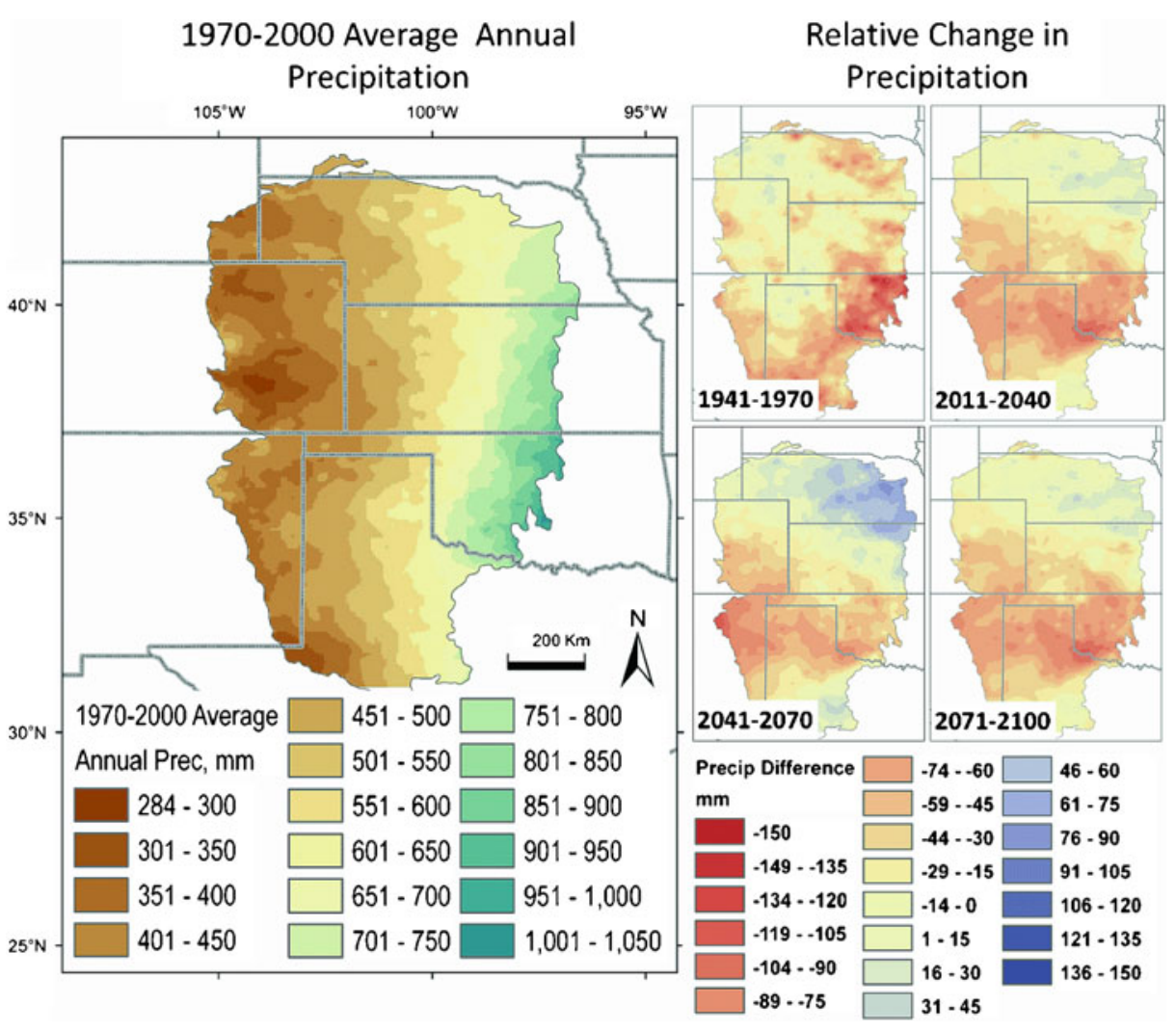

Fig. 3 Left: Average annual precipitation, mm, across the study area for the reference period of 1971-2000. Right: Difference in average annual precipitation during four 30-year periods and the reference period (19712000). Red areas have less precipitation in an average year than the reference period; blue areas have more. Light yellow areas reflect little change. Data from 1940-2000 and 1971-2000 are based on PRISM (Parameter-elevation Regression on Independent Slope Model, from Coulson et al. 2010). Prediction periods (2011-2040, 2041-2070, 2071-2100) used the Canadian Centre for Climate Modeling and Analysis model CGCM2.1MR, scenario A1B (continuing current greenhouse gas emission rates). At this scale, the other eight model/emission scenario combinations showed only minor differences from these maps

central Great Plains have the potential to fill with sediment within 100 years, although the longevity of playas varies across our study area. Playa lifespan is shorter in the northern half of our study area where watersheds are smaller and contain greater relative coverage of cropland. On the other hand, the southern portion of our study area is predicted to experience reduced precipitation which may reduce the likelihood of playa inundation. Given the importance of functional playas, especially in the role of aquifer recharge (Smith 2003), playas with longer expected lifespan may merit additional evaluation for protection. Our models suggest locations for application of more refined tools such as dynamically downscaled climate models that can address storm intensity; LIDAR-based [light detection and ranging] elevation data; local land use identification; and recently developed erosion models for field scale assessments, e.g., Water Erosion Prediction Project (WEPP) and Modified Universal Soil Loss Equation (MUSLE; Soil and Water Conservation Society 2003).

Although climate change likely will not accelerate sediment accumulation rates, it will exacerbate other stressors on wetland condition and quality of wildlife habitat. Higher 
Fig. 4 Top: Variation in playa wetland and watershed characteristics by state. WS: watershed; Avg\% WS Grass: average percentage of watershed in native grassland. State names: $\mathrm{CO}$, Colorado; KS, Kansas; NE, Nebraska; NM, New Mexico; OK, Oklahoma; TX, Texas. Bottom: Variation in watershed extent in Texas and Nebraska. Circular lines delineate playa boundaries, angular lines watersheds, light background is grassland/grass, dark background is cropland, light dashed lines are roads $(\sim 1.6 \mathrm{~km}$ intervals)
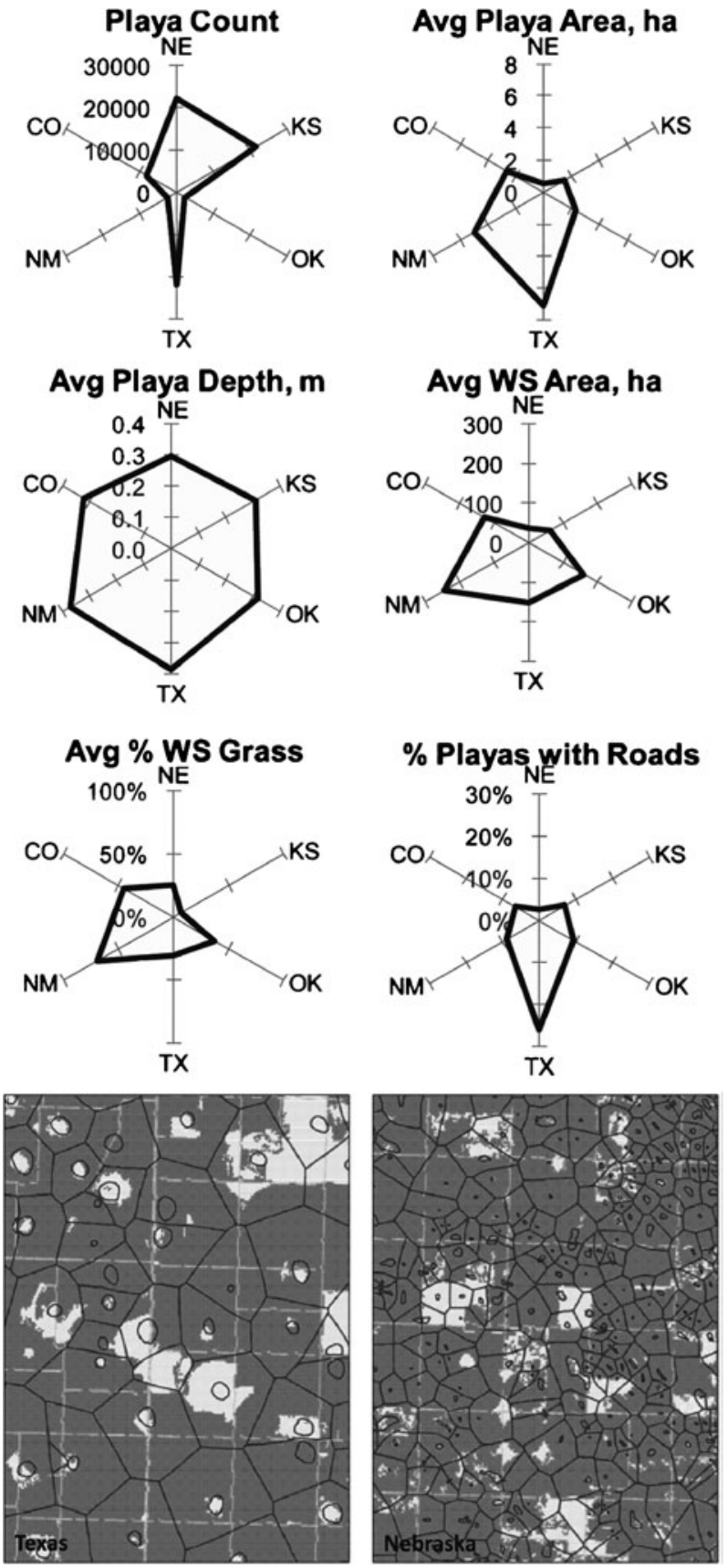

temperatures in concert with reduced precipitation will shorten hydroperiods due to increased evaporation and transpiration rates and less moisture (Christensen et al. 2007). Reduced playa depths due to sedimentation will compound this problem as available water 


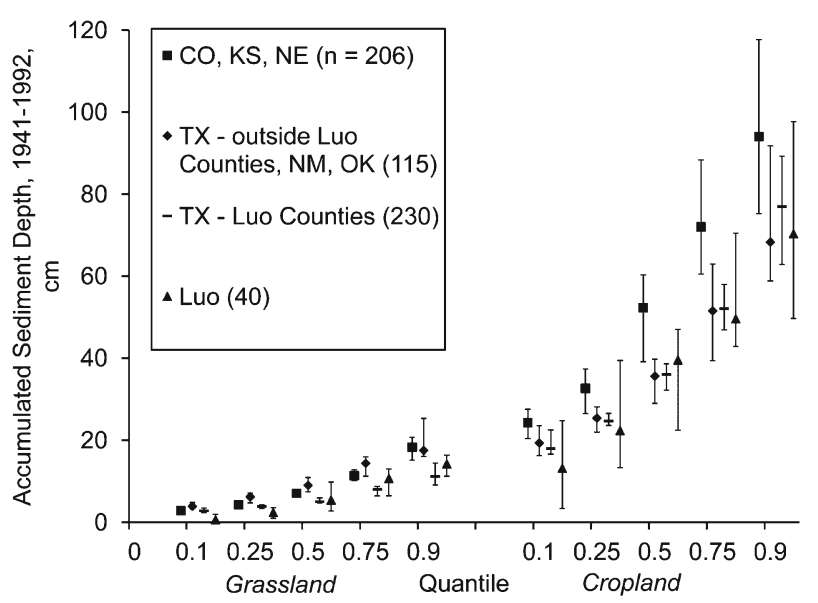

Fig. 5 Expected quantile values and $95 \%$ confidence intervals by geographic area (Luo [1994] source counties; all other counties in Texas, all counties in Oklahoma and New Mexico; and all counties in Colorado, Kansas, and Nebraska) and land use (all grassland or all cropland) for playas meeting Luo (1994) criteria (see Methods)

is spread over a larger surface area (Tsai et al. 2007). Attempts to restore playa functionality through erosion control practices, such as vegetative buffers, may not have the desired effect and may be further confounded by climate change. For example, although Conservation Reserve Program (CRP) plantings (generally nonnative) around wetlands do reduce sedimentation rates and overland contaminants reaching the wetlands (Brinson and Eckles 2011; Johnson 2011; Skagen et al. 2008), playas surrounded by CRP are less likely to be inundated than those in either crop or grassland (Cariveau et al. 2011; O'Connell et al. 2012). This effect is likely to be exacerbated by increasing rates of evapotranspiration.

Although there have been no major changes in the overall amount of agricultural land in this region since the 1940s, future shifts in land use and agricultural practices may be forced by the current unsustainable nature of water use practices in concert with climate change (Brown et al. 2005; Parton et al. 2007). The future of irrigated agriculture in the Great Plains region is intricately linked with the status of the Ogallala aquifer. Since the beginning of major irrigation development in the 1940s, irrigation water has been drawn from the aquifer at unsustainable rates, rates that far exceed recharge, and climatic changes toward warmer and drier conditions are predicted to exacerbate this shortfall (Allen et al. 2005; Rosenberg et al. 1999). In the future, agricultural practices may shift to more sustainable approaches, including added emphasis on dryland rather than irrigated crops or the integration of crop and livestock systems (Allen et al. 2005; Parton et al. 2007). These future agricultural practices potentially may reduce soil erosion and yield lower rates of sediment accumulation in wetlands.

Acknowledgments We thank the U.S. Geological Survey, U.S. Fish and Wildlife Service, and Great Plains Landscape Conservation Cooperative for research funding. Technical support was provided by Colorado State University, Department of Anthropology Geospatial Laboratory. Megan McLachlan and David Pavlacky provided playa information. Linda Joyce and David Coulson provided climate data. David Haukos, Gary Clow, Brian Cade, and Daniel Manier provided technical suggestions. Kevin Schauer processed GIS layers. Any use of trade, product, or firm names is for descriptive purposes only and does not imply endorsement by the United States Government. 
Open Access This article is distributed under the terms of the Creative Commons Attribution License which permits any use, distribution, and reproduction in any medium, provided the original author(s) and the source are credited.

\section{References}

Allen VG, Brown CP, Kellison R et al (2005) Integrating cotton and beef production to reduce water withdrawal from the Ogallala aquifer in the southern high plains. Agron J 97:556-567

Augustine DJ (2010) Spatial versus temporal variation in precipitation in a semiarid ecosystem. Landscape Ecol 25:913-925

Brinson MM, Eckles SD (2011) U.S. Department of Agriculture conservation program and practice effects on wetland ecosystem services: a synthesis. Ecol Appl 21:S116-S127

Brown DG, Johnson KM, Loveland TR, Theobold DM (2005) Rural land-use trends in the conterminous United States, 1950-2000. Ecol Appl 15:1851-1863

Cariveau AB, Pavlacky D (2009) Biological inventory and evaluation of conservation strategies in southwest playa wetlands: Final report to the Nebraska Game and Parks Commission and the Playa Lakes Joint Venture. Rocky Mountain Bird Observatory, Brighton, p 80

Cariveau AB, Pavlacky DC Jr, Bishop AA, LaGrange TG (2011) Effects of surrounding land use on playa inundation following intense rainfall. Wetlands 31:65-73

Christensen JH, Hewitson B, Busuioc A et al (2007) Regional climate projections. In: Solomon S, Qin D, Manning M et al (eds) Climate change 2007: The physical science basis. Contribution of Working Group I to the fourth assessment report of the intergovernmental panel on climate change. Cambridge University Press, New York, pp 849-940

Intergovernmental Panel on Climate Change (2007) Climate change 2007: Synthesis Report. Contribution of Working Groups I, II, and III to the Fourth Assessment Report of the Intergovernmental Panel on Climate Change [Core writing team, Pachauri, R.K. and Reisinger, A. (eds.)]. IPCC, Geneva, Switzerland

Coulson DP, Joyce LA, Price DT, et al (2010) Climate Scenarios for the conterminous United States at the 5 arc minute grid spatial scale using SRES scenarios A1B and A2 and PRISM climatology. USDA Forest Service, Rocky Mountain Research Station, Fort Collins, CO, USA. Available: http://www.fs.fed.us/rm/ data archive/dataaccess/US_ClimateScenarios_grid_A1B_A2_PRISM.shtml

R Development Core Team (2010) R: A language and environment for statistical computing. R Foundation for Statistical Computing, Vienna, Austria. Available from http://www.R-project.org

Ekanayake AJ, Tsai J-S, Allen LJS, Smith LM, Surles JG, Allen EJ (2009) Estimating watershed area for playas in the Southern High Plains, USA. Wetlands 29:387-395

Environmental Systems Research Institute (ESRI) (1999-2008) ArcGIS version 9.3. Redlands, CA, USA

Euliss NH Jr, LaBaugh JW, Fredrickson LH et al (2004) The wetland continuum: a conceptual framework for interpreting biological studies. Wetlands 24:448-458

Ghioca-Robrecht DM, Anderson TA, McMurry ST, Smith LM (2010) Lipid mass and fatty acid composition of Spea spp. in playa wetlands as influenced by land use. Wetlands 30:220-230

Gleason RA, Euliss NH Jr, Hubbard DE, Duffy WG (2003) Effects of sediment load on emergence of aquatic invertebrates and plants from wetland soil egg and seed banks. Wetlands 23:26-34

Gurdak JJ, Roe CD (2010) Review: recharge rates and chemistry beneath playas of the high plains aquifer, USA. Hydrogeol Journal 18:1722-1747

Haukos DA, Smith LM (1994) The importance of playa wetlands to biodiversity of the southern high plains. Landscape Urban Plan 28:83-98

Hutchinson MF (1995) Interpolating mean rainfall using thin plate smoothing splines. Int J GIS 9(4):385-403

SAS Institute (2002-2010) SAS version 9.3, Cary, NC, USA

Johnson LA (2011) Occurrence, function, and conservation of playa wetlands: the key to biodiversity of the southern Great Plains. Dissertation, Texas Tech University, Lubbock, TX, USA

Johnson LA, Haukos DA, Smith LM, McMurray ST (2011a) Loss of playa wetlands caused by reclassification and remapping of hydric soils on the southern high plains. Wetlands 31:483-492

Johnson WP, Rice MB, Haukos DA, Thorpe PP (2011b) Factors influencing the occurrence of inundated playa wetlands during winter on the Texas High Plains. Wetlands 31:1287-1296

Karl TR, Knight RW, Plummer N (1995) Trends in high frequency climate variability in the 20th century. Nature 377:217-220

Koenker R (2010) Quantreg: Quantile Regression. R package version 4.53. http://CRAN.R-project.org/ package $=$ quantreg

Luo H-R (1994) Effects of land use on sediment deposition in playas. Thesis, Texas Tech University, Lubbock, TX, USA 
Luo H-R, Smith LM, Allen BL, Haukos DA (1997) Effects of sedimentation on playa wetland volume. Ecol Appl 7:247-252

McKenney D, Price D, Papadapol P, Siltanen M, Lawrence K (2005) High-resolution climate change scenarios for North America. Frontline Technical Note 107, Canadian Forestry Service, Great Lakes Forestry Centre, Sault Ste. Marie, ON

Natural Resources Conservation Service (2000) National resources inventory, 1997. U.S Department of Commerce, Washington

O'Connell JL, Johnson LA, Smith LM, McMurry ST, Haukos DA (2012) Influence of land-use and conservation programs on wetland plant communities of the semiarid United States Great Plains. Biol Conserv 146:108-115

Parton WJ, Gutmann MP, Williams SA, Easter M, Ojima D (2005) Ecological impact of historical land-use patterns in the Great Plains: a methodological assessment. Ecol Appl 15:1915-1928

Parton WJ, Gutmann MP, Ojima D (2007) Long-term trends in population, farm income, and crop production in the Great Plains. BioScience 57:737-747

Price DT, McKenney DW, Papadopol P, Logan T, Hutchinson MF (2004) High resolution future scenario climate data for North America. Presented at the American Meteorological Society Annual Meetings, Vancouver, August 2004

Renard KG, Freimund JR (1994) Using monthly precipitation data to estimate the R-factor in the revised USLE. J Hydrol 157:287-306

Renard KG, Weeles GR, McCool DK, Yoder DC (1997) Predicting soil erosion by water: a guide to conservation with the revised soil loss equation (RUSLE). Agriculture Handbook No. 703. USDA, Agricultural Research Service, Washington, DC, USA

Rosenberg NJ, Epstein DJ, Wang D, Vail L, Srinivasan R, Arnold JG (1999) Possible impacts of global warming on the hydrology of the Ogallala aquifer region. Clim Chang 42:677-692

Skagen SK, Sharpe PB, Waltermire RG, Dillon MB (1999) Biogeographical profiles of shorebird migration in midcontinental North America. Biological Science Report USGS/BRD/BSR-2000-0003, US Government Printing Office, Denver, CO, USA

Skagen SK, Melcher CP, Haukos DA (2008) Reducing sedimentation of depressional wetlands in agricultural landscapes. Wetlands 28:594-604

Smith LM (2003) Playas of the Great Plains. University of Texas Press, Austin

Smith LM, Haukos DA, McMurry ST, LaGrange T, Willis D (2011) Ecosystem services provided by playas in the high plains: potential influences of USDA conservation programs. Ecol Appl 21:S82-S92

Soil and Water Conservation Society (2003) Conservation implications of climate change: Soil erosion and runoff from cropland. Soil and Water Conservation Society, Ankeny

Tsai J-S, Venne LS, McMurry ST, Smith LM (2007) Influences of land use and wetland characteristics on water loss rates and hydroperiods of playas in the southern high plains. Wetlands 27:683-692

Tsai J-S, Venne LS, McMurry ST, Smith LM (2010) Vegetation and land use impact on water loss rate in playas of the southern high plains. Wetlands 30:1107-1116

Tsai J-S, Venne LS, McMurry ST, Smith LM (2012) Local and landscape influences on plant communities in playa wetlands. J Appl Ecol 49:174-181

Webb EB, Smith LM, Vrtiska MP, Lagrange TG (2010) Effects of local and landscape variables on wetland bird habitat use during migration through the rainwater basin. J Wildl Manage 74:109-119 